Original Research Article

\title{
Effect of age and sex on serum phenytoin concentration in epileptic patients: experience from therapeutic drug monitoring
}

\author{
Shakeel Ahmad Mir*
}

\author{
Department of Clinical \\ Pharmacology, Sher-I-Kashmir \\ Institute of Medical Sciences \\ (SKIMS), Srinagar, Kashmir, \\ India
}

Received: 18 May 2019

Accepted: 02 July 2019

\section{*Correspondence to:}

Dr. Shakeel Ahmad Mir,

Email: shakeel.mir@skims.ac.in

Copyright: (C) the author(s), publisher and licensee Medip Academy. This is an openaccess article distributed under the terms of the Creative Commons Attribution NonCommercial License, which permits unrestricted noncommercial use, distribution, and reproduction in any medium, provided the original work is properly cited.

\begin{abstract}
Background: Phenytoin is a widely prescribed anticonvulsant drug. There is a wide interpatient as well as intrapatient variability in serum phenytoin levels despite standard doses. Phenytoin dosing is challenging because the drug exhibits nonlinear kinetics and interacts with a number of drugs. Children metabolize the drug faster as compared to adults. Ageing is also associated with progressive decline in phenytoin clearance. Many CYP450 enzymes show a sex-dependent difference in activity. The objective for this study was to find the effects of sex and ageing on serum phenytoin levels.

Methods: The influence of sex and ageing on the serum phenytoin levels was evaluated retrospectively in 96 anonymized epileptic patients who had received phenytoin alone for more than four weeks. These patients were divided into three age groups, up to 18 years (children), 19-60 years (adults) and more than 60 years (elderly).

Results: There were $6.25 \%$ children, $84.37 \%$ adults and $9.37 \%$ elderly. The majority $(71.87 \%)$ of patients were males. Children achieved a mean phenytoin level of $15.71 \pm 4.85 \mu \mathrm{g} / \mathrm{ml}$ after a daily dose of $225.00 \pm 75.82 \mathrm{mg}$. Adults attained a mean serum phenytoin level of $16.12 \pm 3.90 \mu \mathrm{g} / \mathrm{ml}$ with a mean daily dose of $282.72 \pm 69.44 \mathrm{mg}$. The elderly achieved a mean serum phenytoin level of $15.85 \pm 2.19 \mu \mathrm{g} / \mathrm{ml}$ after a mean daily dose of $266.67 \pm 70.71 \mathrm{mg}$. As compared to $77.77 \%$ females, $84.05 \%$ males had phenytoin levels in therapeutic range. $50.00 \%$ children, $82.71 \%$ adults, and $100.00 \%$ elderly had phenytoin levels in therapeutic range. There was a correlation between sex, age and serum phenytoin levels $(r=0.003$ to 0.762$)$.

Conclusions: There was a correlation between sex, age and serum phenytoin levels in this study. A better understanding of the effects of sex and age on the clinical pharmacology of phenytoin would enhance the quality of prescribing.
\end{abstract}

Keywords: Age, Epilepsy, Phenytoin, Serum level, Sex, Therapeutic drug monitoring

\section{INTRODUCTION}

Therapeutic drug monitoring (TDM) is based on the principle that for some drugs there is a close relationship between the plasma level of the drug and its clinical effect. Standard or empirical methods of dosing are appropriate for most of the drugs. ${ }^{1}$ TDM is used mainly for monitoring drugs with narrow therapeutic ranges and marked pharmacokinetic variability. ${ }^{2}$
Phenytoin is one of the commonly used drugs for the management of epilepsy in all age groups. ${ }^{3}$ It has certain physicochemical characteristics which make it liable to bioavailability problems. ${ }^{4}$ Phenytoin dosing is challenging because the drug exhibits non-linear pharmacokinetics, zero-order elimination, and a multitude of drug-drug interactions For this reason, drug levels are measured to optimize dosing. ${ }^{5}$ Males and females differ in drug disposition and response. ${ }^{6}$ The ageing process is 
characterized by structural and functional changes affecting all organ systems .Changes in body composition, hepatic and renal function are responsible for prolongation of plasma half-life. Significant pharmacodynamic changes also occur which; in general, tend to increase sensitivity to drugs. ${ }^{7}$

The aim of this study was to study the relationship between sex, age and serum phenytoin levels in epileptic patients and also the relationship between dose and serum phenytoin levels. This knowledge of the behavior of serum phenytoin concentration in individual patients in relation to sex, age and dose would enhance the quality of prescribing.

\section{METHODS}

We retrospectively evaluated 300 anonymized TDM analyses of patients who had received phenytoin alone for more than 4 weeks. All data were derived from the database of the therapeutic drug monitoring service of a tertiary care hospital. 96 patients fulfilling the inclusion criteria were divided into three groups: children (1-18 years), adults (19-60 years) and elderly ( $>60$ years). ${ }^{3}$ Most studies and reviews on the subject have considered the elderly to be 65 years or older, but some have included persons over the age of $60 .^{8}$ The exclusion criteria included samples drawn for evaluating the peak levels; samples from suspected cases of non-compliance or overdose; and, samples from patients with severe renal and/or hepatic disorders. ${ }^{3}$
The total serum phenytoin concentration was measured by a calibrated and validated semi auto analyser (EMIT) made by Transaisa India and reagent used was made by Siemens Healthcare USA. Drug levels were categorized into subtherapeutic $(<10 \mu \mathrm{g} / \mathrm{ml})$, therapeutic $(10-20 \mu \mathrm{g} / \mathrm{ml})$, supratherapeutic $(20-40 \mu \mathrm{g} / \mathrm{ml}) .{ }^{3}$ Age and sex, recorded at the time of blood sampling were used to assess the influence of these physiological factors on serum phenytoin concentration. ${ }^{9}$

\section{Statistical analysis}

After the completion of data collection, it was analysed to check identifiable errors and incompleteness. The data was analysed by Statistical Package for the Social Sciences (SPSS) version 20.

\section{RESULTS}

\section{Males}

Constituted $71.87 \%$ of study population $(n=69)$ and the mean age was $37.77 \pm 16.32$ years (Table 1). Mean dose was $268.52 \pm 66.72 \mathrm{mg} /$ day and mean phenytoin level was $16.08 \pm 3.53 \mu \mathrm{g} / \mathrm{ml}$ (Table 2). 5.79\%patients $(n=4)$ had sub therapeutic serum phenytoin levels, 84.05\% $\quad(n=58)$ therapeutic and $10.14 \%(n=7)$ supra-therapeutic levels (Table 3). Pearson correlation between dose and level was weak $(r=0.195)$ and the correlation between age and level was also weak $(\mathrm{r}=0.043)$ (Table 4).

Table 1: Characteristics of study population( $n=96)$.

\begin{tabular}{|lllllll|}
\hline Group & Male & Female & Total & Min. age & Max. age & Mean age \pm SD \\
\hline Total & $69(71.87 \%)$ & $27(28.12 \%)$ & $96(100.00)$ & 3 & 80 & $38.60 \pm 16.41$ \\
\hline Up to 18 years & 4 & 2 & $6(6.25 \%)$ & 3 & 18 & $13.17 \pm 5.70$ \\
\hline 19-60 years & 59 & 22 & $81(84.37 \%)$ & 19 & 60 & $37.00 \pm 12.39$ \\
\hline$>60$ years & 6 & 3 & $9(9.37 \%)$ & 65 & 80 & $70.00 \pm 4.84$ \\
\hline
\end{tabular}

Table 2: Daily dose and serum phenytoin concentration in different groups.

\begin{tabular}{|c|c|c|c|c|c|c|}
\hline \multirow{2}{*}{ Group } & \multicolumn{3}{|c|}{ Daily dose (mg/Day) } & \multicolumn{3}{|c|}{ Measured serum level ( $\mu \mathrm{g} / \mathrm{ml})$} \\
\hline & Min & Max & Mean \pm SD & Min & Max & Mean \pm SD \\
\hline Males Total & 100 & 400 & $268.52 \pm 66.72$ & 7.00 & 25.00 & $16.08 \pm 3.53$ \\
\hline Females Total & 100 & 400 & $282.60 \pm 71.65$ & 8.00 & 26,00 & $16.06+4.51$ \\
\hline Up to 18 years & 100 & 300 & $225.00 \pm 75.82$ & 9.00 & 21.50 & $15.71 \pm 4.85$ \\
\hline Males & 100 & 300 & $212.50 \pm 85.39$ & 9.00 & 20.20 & $15.30 \pm 2.35$ \\
\hline Females & 200 & 300 & $250.00 \pm 70.71$ & 11.60 & 21.50 & $16.55 \pm 4.95$ \\
\hline 19 to 60 years & 100 & 400 & $282.72 \pm 69.44$ & 7.00 & 26.00 & $16.12 \pm 3.90$ \\
\hline Males & 100 & 400 & $288.98 \pm 68.27$ & 7.00 & 25.00 & $16.23 \pm 3.58$ \\
\hline females & 100 & 400 & $265.91 \pm 71.35$ & 8.00 & 26.00 & $15.82 \pm 4.73$ \\
\hline$>60$ years & 100 & 300 & $266.67 \pm 70.71$ & 11.00 & 18.00 & $15.85 \pm 2.19$ \\
\hline Males & 100 & 300 & $250.00 \pm 34.15$ & 11.00 & 17.00 & $15.03 \pm 2.23$ \\
\hline Females & 300 & 300 & 300.00 & 16.50 & 18.00 & $15.85 \pm 2.19$ \\
\hline
\end{tabular}


Table 3: Serum Phenytoin levels in different groups.

\begin{tabular}{|llll|}
\hline Group & Sub-therapeutic level & Therapeutic Level & Supra-therapeutic \\
\hline Males $(\mathrm{n}=69)$ & $4(5.79 \%)$ & $58(84.05 \%)$ & $7(10.14 \%)$ \\
\hline Females $(\mathrm{n}=27)$ & $3(11.11 \%)$ & $21(77.77 \%)$ & $3(11.11 \%)$ \\
\hline Total $(\mathrm{n}=96)$ & $7(7.29 \%)$ & $79(82.29 \%)$ & $10(10.41 \%)$ \\
\hline Children $(\mathrm{n}=6)$ & $1(16.66 \%)$ & $3(50.00 \%)$ & $2(33.33 \%)$ \\
\hline Adults $(\mathrm{n}=81)$ & $6(7.40 \%)$ & $67(82.71 \%$ & $8(9.87 \%)$ \\
\hline Elderly $(\mathrm{n}=9)$ & - & $9(100.00 \%)$ & - \\
\hline
\end{tabular}

Table 4: Pearson correlations ( $r$ ) of different variable pairs.

\begin{tabular}{|lll|}
\hline \multirow{2}{*}{ Group } & Pair & $\mathbf{r}$ \\
\hline \multirow{3}{*}{ Females } & Age and level & 0.043 \\
\cline { 2 - 3 } & Dose and Level & 0.195 \\
\hline \multirow{3}{*}{ Children } & Age and level & 0.120 \\
\cline { 2 - 3 } & Dose and Level & 0.443 \\
\hline \multirow{3}{*}{ Adults } & Age and Level & 0.737 \\
\cline { 2 - 3 } & Gender and level & 0.133 \\
\cline { 2 - 3 } & Dose and Level & 0.762 \\
\hline \multirow{3}{*}{ Elderly } & Age and level & 0.084 \\
\cline { 2 - 3 } & Gender and Level & 0.046 \\
\cline { 2 - 3 } & Dose and level & 0.231 \\
\hline \multirow{3}{*}{ Overall } & Age and Level & 0.110 \\
\cline { 2 - 3 } & Gender and Level & 0.562 \\
\cline { 2 - 3 } & Dose and Level & 0.118 \\
\cline { 2 - 3 } & Age and Level & 0.068 \\
\cline { 2 - 3 } & Gender and Level & 0.003 \\
\hline
\end{tabular}

\section{Females}

Constituted $28.12 \%$ of study population $(n=27)$ and the mean age was $40.74 \pm 16.76$ years. (Table 1 ). Mean dose was $282.60 \pm 71.65 \mathrm{mg} /$ day and mean drug level was $16.06 \pm 4.51 \mu \mathrm{g} / \mathrm{ml}$ (Table 2$) .11 .11 \%$ patients $(\mathrm{n}=3)$ had sub therapeutic serum phenytoin levels, $77.77 \%(\mathrm{n}=21)$ therapeutic and $11.11 \%(\mathrm{n}=3)$ supra-therapeutic levels (Table 3). Pearson correlation between dose and level was moderate $(r=0.443)$ and the correlation between age and level was weak $(r=0.120)$ (Table 4).

\section{Children}

Constituted $6.25 \%$ of study population $(n=6)$ and the mean age was $13.17 \pm 5.70$ years (Table 1). Mean dose was $225.00 \pm 75.82 \mathrm{mg} /$ day and mean drug level was $15.71 \pm 4.85 \mu \mathrm{g} / \mathrm{ml}$. The mean dose in male children was $212.50 \pm 85.39 \mathrm{mg} /$ day and produced a mean level of $15.30 \pm 2.35 \mu \mathrm{g} / \mathrm{ml}$. The mean dose in female children was $250.00 \pm 70.71 \mathrm{mg} /$ day and produced a mean level of $16.55 \pm 4.95 \mu \mathrm{g} / \mathrm{ml}$ (Table 2$) .16 .66 \%$ children $(\mathrm{n}=1)$ had sub therapeutic serum phenytoin levels, $50.00 \% \quad(n=3)$ therapeutic and $33.33 \% \mathrm{n}=2$ ) supra-therapeutic levels (Table 3). Pearson correlation between dose and level $(\mathrm{r}=0.762)$ and age and level $(\mathrm{r}=0.737)$ was strong. But the correlation between gender and level was weak $(r=0.133)$ (Table 4).

\section{Adults}

Constituted $84.37 \%$ of study population $(n=81)$ and the mean age was $37.00 \pm 12.39$ years (Table 1). Mean dose was $282.72 \pm 69.44 \mathrm{mg} /$ day and mean drug level was $16.12 \pm 3.90 \mu \mathrm{g} / \mathrm{ml}$. The mean dose in male adults was $288.98 \pm 68.27 \mathrm{mg} /$ day and produced a mean level of $16.23 \pm 3.58 \mu \mathrm{g} / \mathrm{ml}$. The mean dose in female adults was $265.91 \pm 71.35 \mathrm{mg} /$ day and produced a mean level of $15.82 \pm 4.73 \mu \mathrm{g} / \mathrm{ml}$ (Table 2). $7.40 \%$ adults $(\mathrm{n}=6)$ had sub therapeutic serum phenytoin levels, $82.71 \%$ therapeutic $(n=67)$ and $9.87 \%(n=8)$ supra-therapeutic levels (Table 3). Pearson correlation between dose and level was weak $(\mathrm{r}=0.231)$ and the correlation between gender and level was also weak $(r=0.046)$ (Table 4).

\section{Elderly}

Constituted $9.37 \%$ of study population $(n=9)$ and the mean age was $70.00 \pm 4.84$ years (Table 1 ). Mean dose was $266.67 \pm 70.71 \mathrm{mg} /$ day and mean drug level was $15.85 \pm 2.19$ $\mu \mathrm{g} / \mathrm{ml}$. The mean dose in male adults was $250.00 \pm 34.15$ $\mathrm{mg} /$ day and produced a mean level of $15.03 \pm 2.23 \mu \mathrm{g} / \mathrm{ml}$. The mean dose in female adults was $300.00 \mathrm{mg} /$ day and produced a mean level of $15.85 \pm 2.19 \mu \mathrm{g} / \mathrm{ml}$ (Table 2) All the elderly patients had phenytoin levels in therapeutic range (Table 3). Pearson correlation between dose and level was weak $(r=0.118)$ and the correlation between gender and level was strong $(r=0.562)$ (Table 4).

\section{DISCUSSION}

Phenytoin dosing is challenging because of capacitylimited metabolism, interindividual variability, ethnic differences and drug interaction with concomitantlyadministered medications. ${ }^{5}$ There is not only a wide variation in the serum levels of phenytoin between individual patients, but perhaps even within the same patient at differing times. ${ }^{10}$ Differences in metabolism are believed to be the major cause of differential pharmacokinetics between men and women. ${ }^{11}$ Many CYP450 enzymes show a sex-dependent difference in activity. Activities of these enzymes can also change 
during pregnancy and with the use of oral contraceptives. Significant hormonal changes in menopausal and postmenopausal women can also lead to altered drug disposition in women. It is now generally accepted that extremes of age, also have an effect on drug metabolism and clearance. Age-associated reductions in function of some but not all cytochrome P450 enzymes (CYPs) have been described. ${ }^{12}$ In elderly pharmacokinetic changes occur in absorption, distribution, metabolism, and elimination. Gastric secretion, blood flow, and gastrointestinal motility are lower, and these may affect absorption. Reduction in serum albumin levels leads to reduction in protein binding and increase in free fraction of the drug. This is particularly significant for highly protein bound drugs such as phenytoin, carbamazepine, and valproic acid. ${ }^{8}$ Therefore, dosage optimization may be needed to maintain drug efficacy and safety in these subgroups. ${ }^{13}$

Table 5: Significance level of gender differences in different age groups in relation to mean phenytoin dose and mean serum levels.

\begin{tabular}{|lllllll|}
\hline variable & Children & \multicolumn{2}{c}{ Adults } & \multicolumn{3}{c|}{ Elderly } \\
& $\mathbf{t}$ & $\mathbf{p}$ & $\mathbf{t}$ & $\mathbf{p}$ & $\mathbf{t}$ & $\mathbf{p}$ \\
\hline Male vs female (Mean daily dose) & -12.589 & 0.050 & -22.929 & 0.028 & -11.163 & 0.057 \\
\hline Male vs Female (Mean serum level) & -115.400 & 0.006 & -20.603 & 0.031 & -154.88 & 0.004 \\
\hline
\end{tabular}

Table 6: Significance level of dose and serum level in different age groups.

\begin{tabular}{|l|l|l|l|l|l|l|}
\hline Variable & \multicolumn{2}{l}{ Children vs adults } & \multicolumn{2}{l|}{ Children vs elderly } & \multicolumn{3}{l|}{ Adults vs elderly } \\
& t & p & t & p & t & p \\
\hline Mean dose & -8.898 & 0.071 & -12.015 & 0.053 & -31.545 & 0.020 \\
\hline Mean level & -48.864 & 0.031 & -33.209 & 0.019 & -22.811 & 0.028 \\
\hline
\end{tabular}

The present study was conducted to find the effects of age, and gender on serum phenytoin concentration and to find a relationship between phenytoin dose and serum levels achieved. Majority of the patients $(82.29 \%)$ had phenytoin serum concentration within therapeutic range despite receiving lesser than recommended dose. This could be due to genetically slow metabolism in north Indian population. ${ }^{3}$ In this study female patients achieved lower serum phenytoin concentration as compared with men despite of higher mean daily dose. Similar findings were seen by Houghton et al. ${ }^{9}$ In one more study it has been reported that women have a lower mean serum phenytoin concentration than men treated with an identical dose $/ \mathrm{kg}$ of body weight although the difference was not statistically significant. ${ }^{9}$ The correlation between various variables studied and serum concentration was weak to strong.(Table 3) We found a week positive correlation between serum phenytoin concentration and age. Houghton et al, also found a similar correlation. ${ }^{9}$ authors found most of the patients $(82.29 \%)$ in therapeutic range. Sangeeta et al. also found maximum number of patients in therapeutic range. ${ }^{3}$ Author compared mean phenytoin dose and achieved serum levels between males and females in all age groups and found significant differences. (Table 5) authors also compared mean dose and serum levels of different age groups and found significant differences in mean serum levels as shown in (Table 6) As compared to young adults, in elderly the differences were highly significant. Malley et al. also observed that as compared to young adults the elderly have decreased ability to metabolize drugs and this may contribute to the known high incidence of adverse drug reactions in the elderly. ${ }^{14}$

\section{CONCLUSION}

Characterizing the pharmacokinetics and pharmacodynamics of a drug in diverse populations is essential in improving therapeutic effectiveness while minimizing adverse events. A better understanding of the effects of sex and ageing on the clinical pharmacology of therapeutic agents would enhance the quality of prescribing. It is concluded that besides various other factors, sex, and age should also be considered for optimal dosing of patients with Phenytoin.

This is a single institution study on a small number of patients and adds to our understanding of effects of sex and age on serum phenytoin levels. But it is difficult to draw a definite conclusion from observations on a small number of patients. The results may not be applicable to the general population. For better understanding of the effects of sex and age on serum phenytoin levels, further multicentre studies involving large number of patients are required.

\section{ACKNOWLEDGEMENTS}

The author wishes to thank Danish Shakeel, CSE-IBM student of Chandigarh University, Mohali, Punjab, India for helping in tabulation and statistical analysis of data. 
Funding: No funding sources

Conflict of interest: None declared

Ethical approval: The study was approved by the Institutional Ethics Committee

\section{REFERENCES}

1. Suthakaran C, Adithan C. Chapter-7 therapeutic drug monitoring- concepts, methodology, clinical applications and limitations. Health Administrator. 2006;19(1):22-6.

2. Kang JS, Lee MH (2009) Overview of therapeutic drug monitoring. Korean J Intern Med. 2009;24(1):110 .

3. Sharma S, Tabassum F, Dwivedi P, Agarwal R, Kushwaha S, Bala K, et al. Critical appraisal of serum phenytoin variation with patient characteristics in a North Indian population. Neurol Ind. 2015;63(2):2028.

4. Neuvonen PJ. Bioavailability of phenytoin: clinical pharmacokinetic and therapeutic implications. Clin Pharmacokinet. 1979;4(2):91-103.

5. Krasowski MD, Penrod LE. Clinical decision support of therapeutic drug monitoring of phenytoin: Measured versus adjusted phenytoin plasma concentrations. BMC Med Inform Decis Mak. 2012;12(1):7.

6. Offie PS, Sarah HC, Donald RM. Sex Differences in Drug Disposition. J Biomed Biotechnol. 2011; 187103

7. Mangoni AA, Jackson SHD. Age-related changes in pharmacokinetics and pharmacodynamics: basic principles and practical applications. $\mathrm{Br} \mathrm{J}$ Clin Pharmacol. 2003;57(1):6-8.

8. Acharya JN, Acharya VJ. Epilepsy in the elderly: special considerations and challenges. Ann Indian Acad Neurol. 2014;17(Suppl 1):S18-26.

9. Houghton GW, Richens A, Leighton M. Effect of age, height, weight and sex on serum phenytoin concentration in epileptic patients. $\mathrm{Br} \mathrm{J}$ Clin Pharmacol. 1975;2(3):251-6.

10. Turnbull DM, Rawlins MD, Weightman D, Chadwick DW. "Therapeutic" serum concentration of phenytoin: the influence of seizure type. J Neurol Neurosurg Psychiatry. 1984;47(3):231-4.

11. Waxman DJ, Holloway MG. Sex differences in the expression of hepatic drug metabolizing enzymes. Molecular Pharmacol. 2009;76(2):215-28.

12. Kinirons MT, O'Mahony MS. Drug metabolism and ageing. Br J Clin Pharmacol 2004; 57 (5): 540-4

13. Chu T. Gender differences in pharmakokinectics. US Pharmacist. 2014;39(9):40-3.

14. O'Malley K, Crooks J, Duke E, Stevenson IH. Effect of age and sex on human drug metabolism. Br Med $\mathrm{J}$ 1971;3(5775):607-9.

Cite this article as: Mir SA. Effect of age and sex on serum phenytoin concentration in epileptic patients: experience from therapeutic drug monitoring. Int J Basic Clin Pharmacol 2019;8:171721. 